\title{
PENGECETAN TROTOAR
}

NURANI

NIM: : 9173770410369

EMAIL: Nurani21093@gmail.com

\section{Bentuk Kegiatan}

Pengecetan Trotoar di

Dusun Balangloe, Desa

Balangloe Tarowang

\section{Lokasi}

Dusun Balangloe, Desa Balangloe tarowang, kec. Tarowang

\section{Hari/Tanggal dan Waktu}

Pada hari Kamis Tanggal

22 Oktober 2020

Jam 07:30

4.Peserta yang Dilibatkan -Peserta KKLP.

\section{Alasan Diadakannya}

Pengecetan Ulang Trotoar Agar Trotoar terlihat cerah setelah di cat, bersih dan rapi dan Indah Di pandang

\section{Tujuan dan Manfaat}

\section{- Tujuannya}

Agar menyemarakkan dan menghidupkan warna trotoar
- Manfaat

Dapat menambahkan kenyamanan pengguna jalan yang melintas

7. Produk Kegiatan (Jika Ada)

-Cat

-Kuas

-Air

-Ember

\section{Deskripsi Kegiatan}

Melakukan pengecetan trotoar pada tanggal 22 Oktober 2020. Pada Jam 07:30 di Dusun Balangloe Tarowang, Desa Balngloe Tarowang, Kecematan Jeneponto Untuk memper Indah Trotoar dan Memperbarui Cat Agar Lebih Nampak 


\section{Referensi Wajib}

- HERIANTO, H., \& Amir, A. S. (2020, September 10). Pedoman Pelaksanaan Kuliah Kerja Lapangan Plus (KKLP) Mahasiswa STIE dan STKIP YAPTI Jeneponto. https://doi.org/10.31219/osf.io/7dvpk 